\title{
Effects of Heavy Metals Pollution on Some Fish and Mollusc Species from Port Sudan, Sudan
}

\author{
Issra Mohammed Osman Mahjoub ${ }^{1, ~ *, ~ M o h a m e d ~ E l a m i n ~ H a m z a ~}{ }^{2,3}$ \\ ${ }^{1}$ Department of Fisheries, College of Natural Resources and Environmental Studies, University of Bahri, Khartoum, Sudan \\ ${ }^{2}$ Department of Chemistry and Biology, Faculty of Science and Technology, Merowe University of Technology, Merowe, Sudan \\ ${ }^{3}$ Institute of Marine Research, Red Sea University, Port Sudan, Sudan
}

Email address:

israaosman80@hotmail.com(I. M. O. Mahjoub), Maelsaimhu7@gmail.com (M. E. Hamza)

${ }^{*}$ Corresponding author

\section{To cite this article:}

Issra Mohammed Osman Mahjoub, Mohamed Elamin Hamza. Effects of Heavy Metals Pollution on Some Fish and Mollusc Species from Port Sudan, Sudan. Modern Chemistry. Vol. 8, No. 3, 2020, pp. 33-39. doi: 10.11648/j.mc.20200803.11

Received: June 24, 2020; Accepted: November 4, 2020; Published: November 16, 2020

\begin{abstract}
The effects on fishes Lethrinus harak and Cephalopholis minata and on the mollusc Tridacna maxima exposed to different concentrations of heavy metals vanadium, nickel, and copper were investigated. The study indicated that the LC50 for nickel were $198.200 \mathrm{ppm}$, for L. harak, $196.041 \mathrm{ppm}$ for C. minata and $198.200 \mathrm{ppm}$ for T. maxima. The LC50 for copper were $197.175 \mathrm{ppm}$ for L. harak, $272.932 \mathrm{ppm}$ for C. minata and $272.841 \mathrm{ppm}$ in T. maxima. However, LC50 for vanadium recorded $131.836 \mathrm{ppm}$ for L. harak, $164.769 \mathrm{ppm}$ for C. minata and $164.037 \mathrm{ppm}$ for T. maxima. On the other hand, LT50 due to nickel exposure recorded $74.815,47.963$, and 95.116 hours, for L. harak, C. minata and T. maxima, respectively. LT50 due to copper recorded 35.041, 47.681, and 71.835 hours for L. harak, C. minata and T. maxima, respectively. However, LT50 for vanadium were $11.989,47.511$ and 5.792 hours for L. harak, C. minata and T. maxima, respectively. In this study no response was detected in lower concentrations of nickel and copper i.e. $4 \mathrm{ppm}$ and $32 \mathrm{ppm}$, however a high response was detected with the same concentrations of vanadium. The study indicated that T. maxima, was more tolerant for heavy metals pollution than L. harak and C. minata. Nickel concentrations detected in tissues analysis were 0.561-0.04 ppm, 0.421-0.02 ppm and 0.871$0.03 \mathrm{ppm}$ for L. harak, C. minata and T. maxima, respectively. While copper concentrations recorded 1.1030-0.09 ppm, 0.4060-0.02 ppm and 1.35-0.03 ppm for L. harak, C. minata and T. maxima, respectively. However, vanadium concentrations, recorded 0.010-0.00 ppm, 0.04-0.014-0.01 ppm and 0.042-0.00 ppm for L. harak, C. minata, and T. maxima, respectively.
\end{abstract}

Keywords: Heavy Metals, Fish, Mollusca, Pollution, Red Sea, Sudan

\section{Introduction}

Marine pollution is a global environmental problem mostly attributed to human activities on land, water and air. Sediments and organisms releasing potentially toxic substances into the water also contribute to the level of contamination. Contaminants can stay in the water in dissolved form or they can be removed from the water column through sedimentation [1]. On the other hand oil pollution was dangerous from its discovery throughout stages of production, transportation, refining, processing, storage, marketing and even disposal of used products. This was resulted in bioaccumulation and physical contamination of beaches. The seas and oceans were polluted by millions of tons of oil annually since most of the factories and refineries were built along the coast [2]. In Japan, as a result of discharge of waste water containing mercury in Port Minamata bioaccumulation in tissues of marine organisms occurred and led to cases of poisoning in 1952 known as Minamata syndrome [3]. The marine biota and habitat of Port Sudan area were negatively affected by discharge of harmful substances into the marine environment or indirectly from land based activities [4]. However, assessment and effects of heavy metals pollution at the Sudanese Red Sea coast were also studied $[5,6]$.

Sudan has become an oil exporting country since 1999 and two ports (Bashayer I and Bashayer II) were constructed for oil export and import. Approximately 400,000 barrel were exported per day since the mid of 2006. However, few and 
small oil spills were often recorded in the area within and adjacent the port (Ministry of Oil, personal communication). Many scientists have designed methods for measuring lethal levels of pollutants for aquatic organisms, thus, nearly all the acute lethal actions ceased were within four days and halflethal concentration LC50 $[7,8]$.

Major chronic inshore marine pollution problems can often be attributed to the discharge of large volumes of wastes that have local impacts. These include materials which are partially biodegradable, such as raw sewage sludge, food and beverage processing work, pulp and paper mill effluents, woolen and cotton gin waste, and sugar refinery effluents, also solid wastes were in this category [9]. The area around Port Sudan was polluted, being a harbour for oil and gas product export and import, in addition to impacts of the existing industrial areas in Port Sudan town. Similarly the atmosphere near the power plant station was polluted with vapors and gases emitted by power generators, and black fumes are seen at the time of generators operation. Also the traffic participates in atmosphere pollution, which ends at the marine environment. Oil film was also seen covering part of water surface in this site, which was regarded as a nursery ground. However fingerlings were seen in the tidal area, in spite of oil film in Alkheir oil terminal (refined products), the area was exposed to oil pollution through handling, spills from tankers, ballast waters, etc. The Red Sea is considered as semi-enclosed area that exposed and threatened by pollution, stated that due to its relatively small size, limited oceanographic circulation and high endemism, the Red Sea is particularly vulnerable to pollution, loss of species, and reduction in ecosystem productivity. Accidents may happen during oil import and export operations [10]. Oil contains high level of heavy metals (according to analysis of Petroleum Central Laboratory). Since these heavy metals enter the water it was well expected to find its way to aquatic organisms.

\section{Material and Methods}

\subsection{Experiment Setup}

Over 50 live specimens from each of fishes Lethrinus harak and Cephalopholis minata and Mollusca Tridacna maxima were collected by local fishers form Abu Hashish area in Port Sudan, Red Sea State -Sudan. The specimens were then transferred to the Red Sea Fisheries Research Centre laboratory, kept in aquariums and were acclimatized to laboratory conditions. Deformed specimens or that showed abnormal behaviour were instantly rejected. According to modified bioassay methods of a pilot experiment was setup with heavy metals pollutants, vanadium: ammonium vanadate $\mathrm{NH}_{4} \mathrm{VO}_{3}[8,11]$. Copper: cupric nitrate trihydrate. Copper (II) nitrate trihydrate $\mathrm{Cu}\left(\mathrm{NO}_{3}\right)_{2} \cdot 3 \mathrm{H}_{2} \mathrm{O}$ and nickel: nickel nitrate hexahydrate, $\mathrm{Ni}\left(\mathrm{NO}_{3}\right)_{2} \cdot 6 \mathrm{H}_{2} \mathrm{O}$, the concentrations prepared for each metal were: $273 \mathrm{ppm}, 200$ ppm, 165 ppm, 132 ppm, 100 ppm, 64 ppm, 32 ppm, 16 ppm and $4 \mathrm{ppm}$. The pollutants were dissolved in seawater and eight specimens per concentration were tested. The experiment set-up was consisted of nine aquariums each containing 32 liters vigorously aerated sea water $(100 \%$ saturation) and were left at room temperature $\left(22^{\circ} \mathrm{C}-28^{\circ} \mathrm{C}\right)$ and diffused day light. Identified weights of fishes and mollusc specimens (50-70 gm.) were selected. Eight samples from each species were introduced into the experimental system 30 minutes after the introduction of pollutants; an identical control system with pollutant-free water was maintained parallel to each experiment. Water in both systems was regularly aerated for one hr. every $12 \mathrm{hrs}$ to avoid acute depletion of dissolved oxygen. All experiments were carried out in triplicate with the regular feeding for both the experimental and control animals. Observations on L. harak, C. minata and T. maxima mortality were recorded every $3,6,12,24,36,48$ and 72 hrs. Dead specimens were preserved in $10 \%$ formalin for pathological investigation and for Atomic Absorption Spectrophotometer (AAS) analysis. Concentrations of three heavy metals $\mathrm{V}, \mathrm{Ni}$ and $\mathrm{Cu}$ in tissues of fishes and mollusc specimens were determined using (AAS) following [12].

\subsection{Effects of Some Heavy Metals on the Mortality Rate of Specimens}

The effects of exposure of T. maxima, L. harak and C. minata to different concentrations of vanadium, nickel and copper were studied with special reference to their survival (table 1, 2 and 3) survival or reciprocal "mortality" was studied in terms of half-lethal concentration (LC50) and halflethal time (LT50) for the experimental samples (Figures 1, 2 and 3). The mortality values were calculated directly using plots of a cumulative response against pollutants concentration, time of exposure logarithmic-probability paper and from semi logarithmic regression analysis of the same parameters. Cumulative response (\%) when regressed against pollutant concentration (ppm) and lethal time in hours resulted in highly significant predictive equations. The variations of the LT50 for different concentration of pollutants used were presented by histogram for all experimental fish species and mollusc, when the LT50 were plotted against the logarithms of pollutants concentrations (Figures 1-9) and progressive experimental decrease occurred with increase in concentration for both fish and mollusc populations studied.

\section{Results and Discussion}

\subsection{Effects of Vanadium on the Mortality Rate}

The results obtained from this work indicated that the LT50 and LC50 values were low at vanadium treatment, thus, values of LT50 were 11.989 hours, 5.792 hours and 47.511 hours for L. harak, C. minata and T. maxima, respectively, while that of LC50 were $131.836 \mathrm{ppm}, 164.769 \mathrm{ppm}$ and $164.037 \mathrm{ppm}$ for L. harak, C. minata and T. maxima, respectively (Table 1, Figures 1, 2 and 3). The correlation coefficient between concentrations and mortality was 
significant $(\mathrm{p}<0.05)$ for T. maxima and L. harak, thus, the $\quad(\mathrm{p}<0.001)$. correlation was very highly significant for C. minata

Table 1. Probit analysis of fishes, and mollusc, correlation between concentration (Y) and mortality (X).

\begin{tabular}{llll}
\hline Probit analysis* & Tridacna maxima & Lethrinus harak & Cephalopholis minata \\
\hline LC50 & 164.037 & 131.836 & 164.769 \\
LT50 & 47.511 & 11.989 & 5.792 \\
MCR & 18.23 & 24.67 & 12.04 \\
Correlation coefficient (r) & 0.71 & 0.57 & 0.86 \\
Regression equation Y=a+b In X & Y=5.212-0.283 In X & Y=5.492-0.406 In X & Y=7.632+0.625 In X \\
Correlation significance & 0.027 & 0.041 & 0.001 \\
\hline
\end{tabular}

* Calculated according to method of Finney (1971).

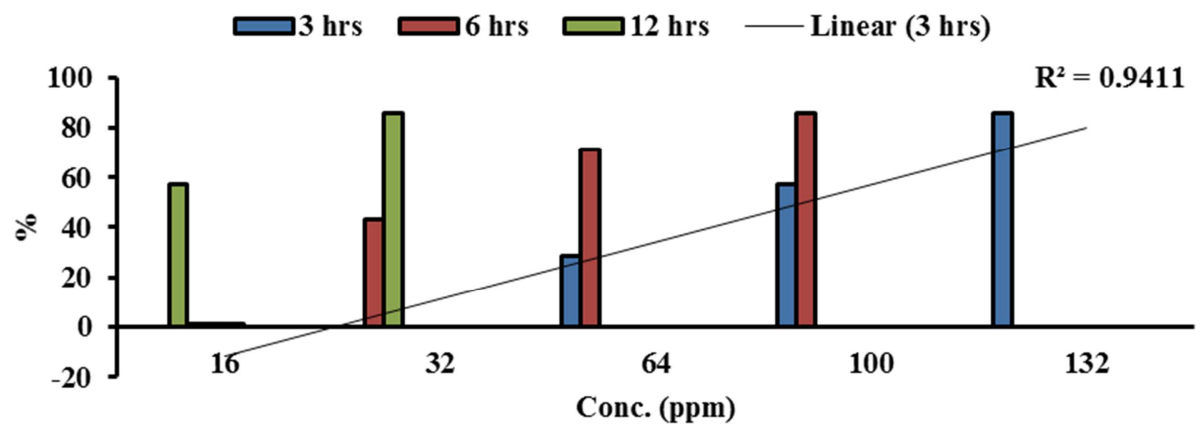

Figure 1. Vanadium effect on Lethrinus harak.

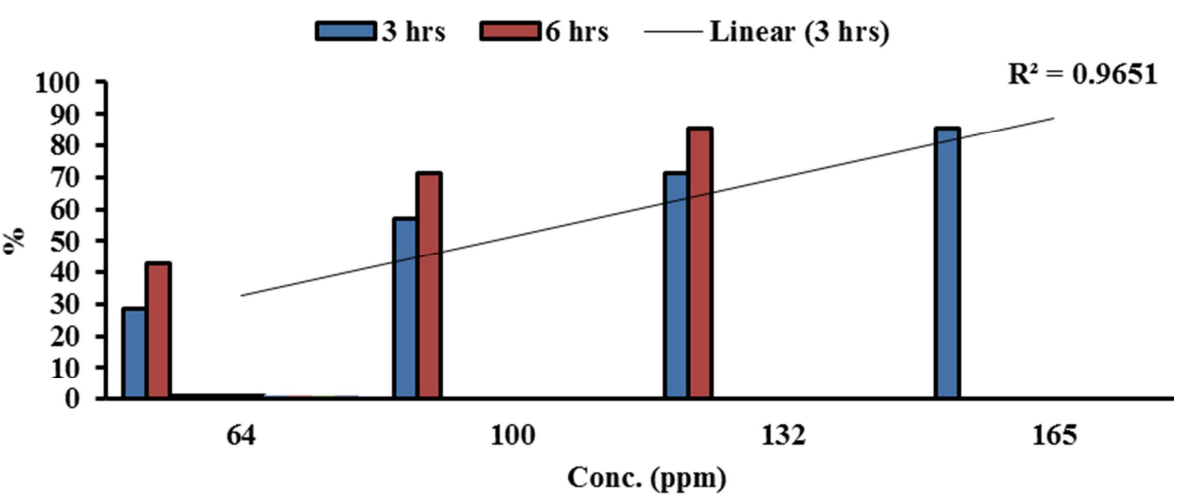

Figure 2. Vanadium effect on Cephalopholis minata.

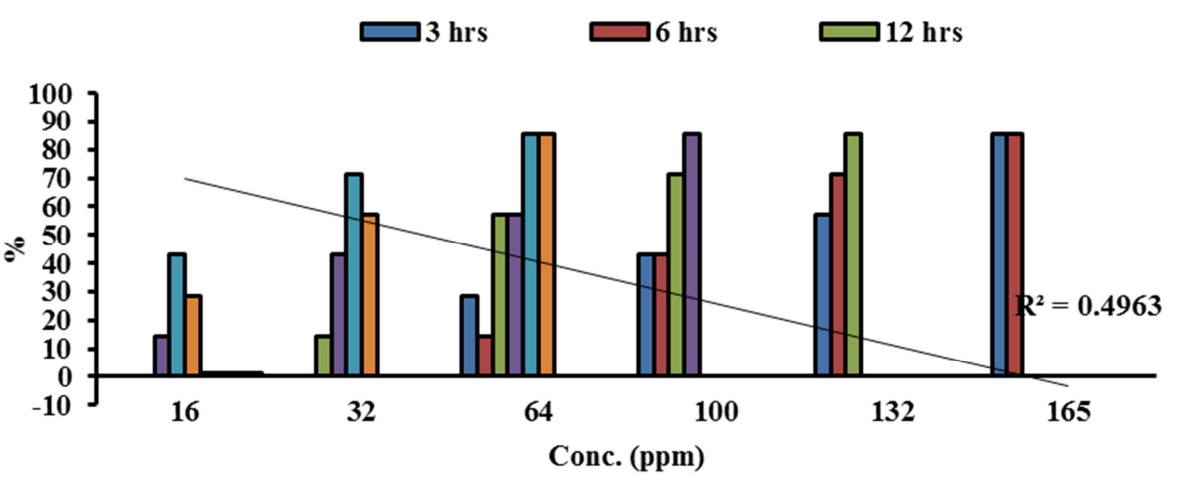

Figure 3. Vanadium effect on Tridacna maxima.

\subsection{Effects of Nickel on the Mortality Rate}

Values of LT50 recorded at nickel treatment were 47.815 hours, 47.963 hours and 95.216 hours for L. harak, C. minata and T. maxima, respectively, while that of LC50 were 199.236 ppm, $196.041 \mathrm{ppm}$ and $198.200 \mathrm{ppm}$ for L. harak, C. minata and T. maxima, respectively (Table 2, Figures 4, 5 and 6). The correlation coefficient between concentrations and mortality was extremely highly significant $(\mathrm{p}<0.000)$ for C. minata and highly significant $(\mathrm{p}<0.01)$ for $\mathrm{T}$. maxima and insignificant ( $p>0.05$ ) for L. harak (table 2 ). 
Table 2. Probit analysis of fishes, and mollusc, correlation between concentration $(Y)$ and mortality $(X)$.

\begin{tabular}{llll}
\hline Probit analysis* & Tridacna maxima & Lethrinus harak & Cephalopholis minata \\
\hline LC50 & 198.200 & 199.236 & 196.041 \\
LT50 & 95.216 & 47.815 & 47.963 \\
MCR & 19.25 & 26.38 & 11.09 \\
Correlation coefficient (r) & 0.72 & 0.69 & 0.81 \\
Regression equation Y=a+b In X & Y $=4.069+0.549$ In x & Y $=4.9922+0.1793$ In x & Y $=4.8796+0.3178$ In x \\
Correlation significance & 0.008 & 0.136 & 0.006 \\
\hline
\end{tabular}

* Calculated according to method of Finney (1971).

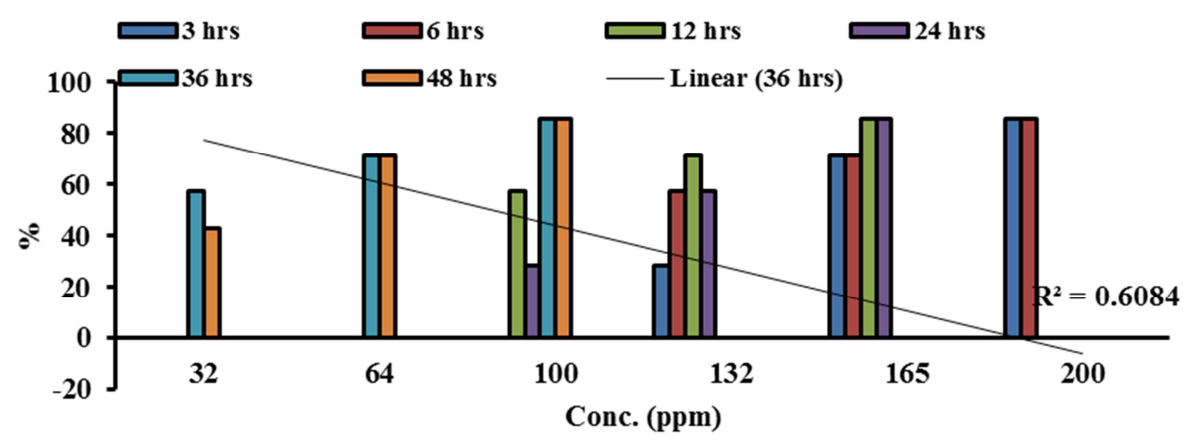

Figure 4. Nikel effect on Lethrinus harak.

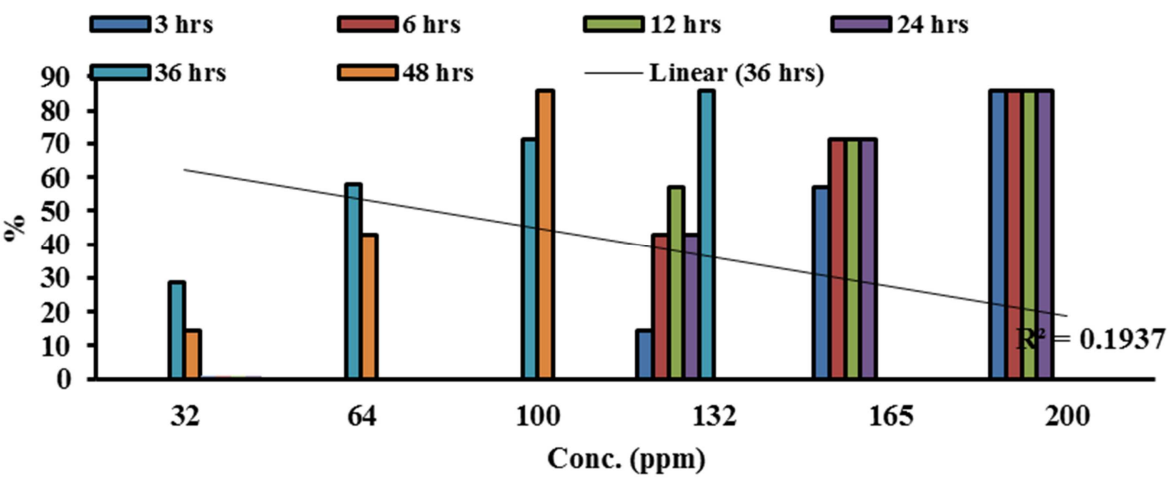

Figure 5. Nikel effect on Cephalopholis minata.

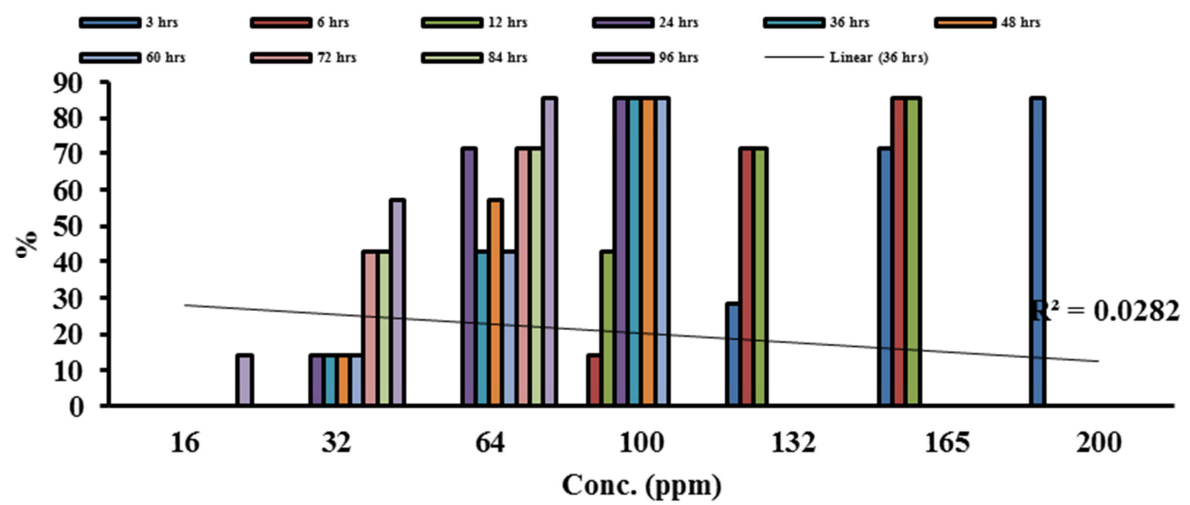

Figure 6. Nikel effect on Tridacna maxima.

\subsection{Effects of Copper on the Mortality Rate}

According to this study LT50 values of copper treatment were 35.041 hours, 47.681 hours and 71.853 hours for L. harak, C. minata and T. maxima, while that of LC50 were 197.175 ppm, 272.932 ppm and 272.841 ppm for L. harak, C. minata and T. maxima, respectively (Table 3, Figures 7, 8 and 9). The correlation coefficients between concentrations and mortality were significant $(\mathrm{p}<0.05)$ for $\mathrm{T}$. maxima and $\mathrm{C}$. minata, while for $\mathrm{L}$. harak the correlation was highly significant $(\mathrm{p}<0.01)$. 
Table 3. Probit analysis of fishes, and mollusc, correlation between concentration $(Y)$ and mortality $(X)$.

\begin{tabular}{llll}
\hline Probit analysis* & Tridacna maxima & Lethrinus harak & Cephalopholis minata \\
\hline LC50 & 272.841 & 197.175 & 15.26557 \\
LT50 & 71.853 & 35.041 & 272.932 \\
MCR & 17.66 & 21.90 & 47.681 \\
Correlation coefficient (r) & 0.74 & 0.80 & 0.85 \\
Regression equation Y=a+ b In X & Y $=4.4244-0.081$ In x & Y $=4.7144+0.169$ In x & Y $=4.6156+0.3247$ In x \\
Correlation significance & 0.012 & 0.003 & 0.012 \\
\hline
\end{tabular}

* Calculated according to method of Finney (1971)

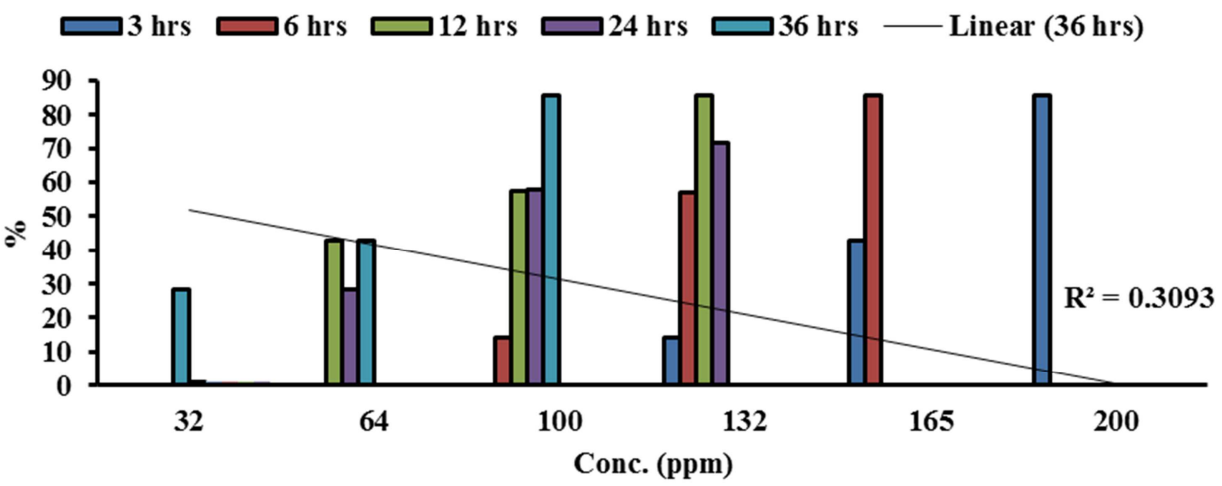

Figure 7. Copper effect on Lethrinus harak.

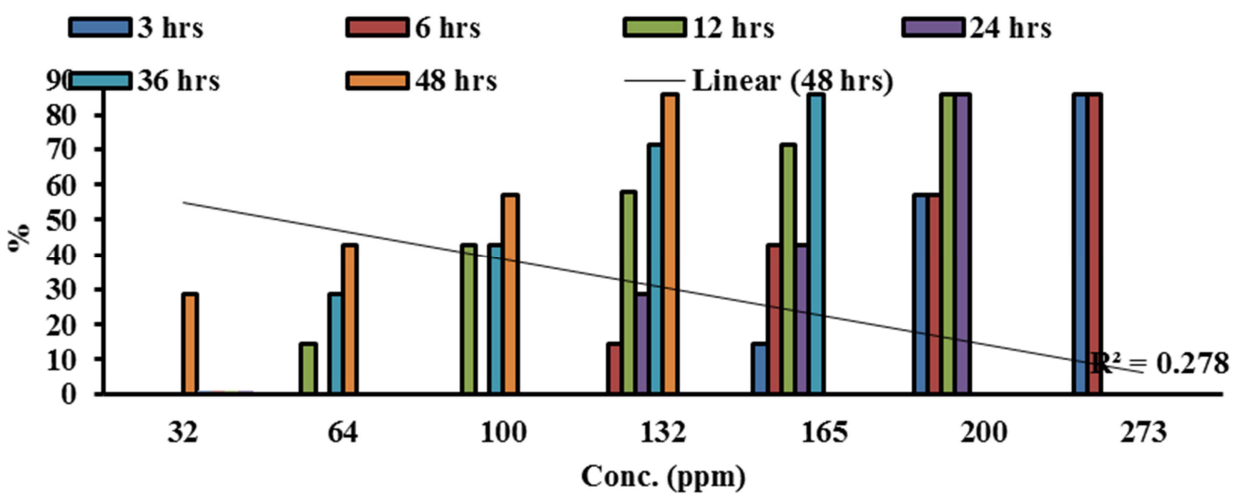

Figure 8. Copper effect on Cephalopholis minata.

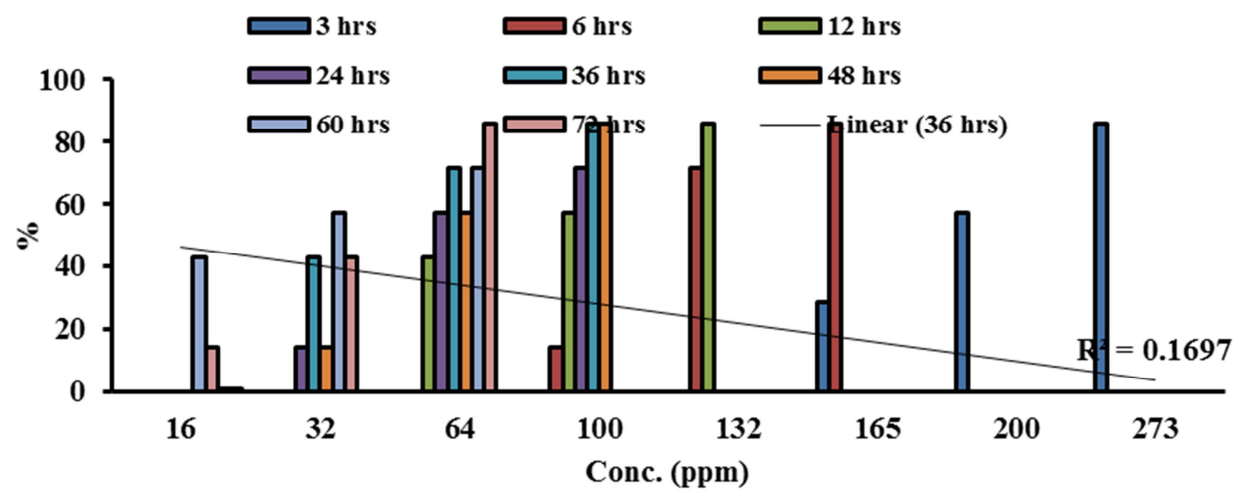

Figure 9. Copper effect on Tridacna maxima.

\subsection{Levels of Heavy Metals in Tissues of Fishes, and Mollusc}

Tables (4, 5 and 6) showed the changes in levels of the studied pollutants in tissues of the experimental animals. It is apparent from Table 4 that, the mean concentration of vanadium was below detection limit in the control. However, the mean concentration between the experimental species was significantly different as indicated by Duncan's multiple range tests. 
Table 4. Vanadium concentration in tissues of fishes, and mollusc.

\begin{tabular}{lll}
\hline Species & Control* & Mean of vanadium \\
\hline Lethrinus harak & Below detection limit. & $0.010 \mathrm{c} \pm 0.00$ \\
Cephalopholis minata & Below detection limit. & $0.014 \mathrm{~b} \pm 0.01$ \\
Tridacna maxima & Below detection limit. & $0.042 \mathrm{a} \pm 0.00$ \\
P-value & 0.0371 & \\
\hline
\end{tabular}

Means bearing different superscripts are significantly different $(\mathrm{p} \leq 0.05)$ according to Duncan's multiple range tests.

It is apparent from Table 5 that, the difference of nickel concentration was highly significant in the experimental samples compared with the control. A significant difference was observed also between the experimental samples as indicated by Duncan's multiple range tests.

Table 5. Nickel concentration in tissues of fishes, and mollusc.

\begin{tabular}{lll}
\hline Species & Control & Mean of nickel \\
\hline Lethrinus harak & $<0.10 \mathrm{~d} \pm 0.00$ & $0.561 \mathrm{~b} \pm 0.04$ \\
Cephalopholis minata & $<0.10 \mathrm{~d} \pm 0.00$ & $0.421 \mathrm{c} \pm 0.02$ \\
Tridacna maxima & $<0.10 \mathrm{~d} \pm 0.00$ & $0.871 \mathrm{a} \pm 0.03$ \\
P-value & 0.0025 & \\
\hline
\end{tabular}

Means bearing different superscripts are significantly different $(\mathrm{P} \leq 0.05)$ according to Duncan's multiple range tests.

Results obtained from Table 6 showed that, the difference of copper concentration was highly significant between the experimental samples and the control. Significant difference was also observed between the experimental samples as indicated by Duncan's multiple range tests.

Table 6. Copper concentration in tissues of fishes, and mollusk.

\begin{tabular}{lll}
\hline Species & Control & Mean of copper \\
\hline Lethrinus harak & $0.1652 \mathrm{~d} \pm 0.08$ & $1.1030 \mathrm{~b} \pm 0.09$ \\
Cephalopholis minata & $0.2820 \mathrm{~cd} \pm 0.07$ & $0.4060 \mathrm{c} \pm 0.02$ \\
Tridacna maxima & $0.0624 \mathrm{~d} \pm 0.01$ & $1.3450 \mathrm{a} \pm 0.08$ \\
P-value & 0.0 & \\
\hline
\end{tabular}

Means bearing different superscripts are significantly different $(\mathrm{P} \leq 0.05)$ according to Duncan's multiple range tests.

With respect to L. harak the mean concentration (ppm) of copper was the highest $(1.1030 \mathrm{~b} \pm 0.09)$, followed by nickel $(0.561 \mathrm{~b} \pm 0.04)$ and the lowest was $0.010 \mathrm{c} \pm 0.00$ for vanadium. However the mean concentration (ppm) of nickel in C. minata was the highest $(0.421 \mathrm{c} \pm 0.02)$, followed by copper $(0.406 \mathrm{c} \pm 0.02)$ and the lowest was vanadium $(0.014 \mathrm{~b} \pm 0.01)$ while $\mathrm{T}$. maxima exhibited the highest mean concentration (ppm) of copper (1.3450a \pm 0.08$)$, followed by nickel $(0.561 \mathrm{~b} \pm 0.04)$ and the lowest was $0.042 \mathrm{a} \pm 0.00$ for vanadium.

This study throws some light on the toxic effects of heavy metals (vanadium, nickel and copper) on fishes and mollusc. The results obtained in this study indicated that the lethal concentrations LC50 of nickel were 199.236 ppm 196.041 ppm and 198.200 ppm for L. harak, C. minata and T. maxima, respectively. Copper recorded 197.175 ppm, $272.932 \mathrm{ppm}$ and $272.841 \mathrm{ppm}$ for L. harak, C. minata and T. maxima, respectively. However, vanadium recorded lower lethal concentrations compared to nickel and copper, these were 131.836 ppm, 164.769 ppm and 164.037 ppm for L. harak, C. minata and T. maxima, respectively, these were agreed with who worked on grass carp (Ctenopharyngodon idella) and silver carp (Hypophthalmichthys molitrix) [13]. It is also in accord with the findings of who studied nickel and copper accumulation in the liver of a freshwater fish Tor putitora. Due to exposure of nickel LT50 were 47.815 hours, 47.963 hours and 95.216 hours for L. harak, C. minata and T. maxima, respectively, and that due to exposure of copper were 35.041 hours, 47.681 hours and 71.853 hours for L. harak, C. minata and $\mathrm{T}$. maxima respectively. However, vanadium recorded 11.989 hours, 5.792 hours and 47.511 hours for L. harak, C. minata and T. maxima respectively. These results confirmed that mollusc T. maxima were more tolerant than the two fish species [14].

Values of heavy metals concentrations recorded in tissues of the experimental samples were $0.561-0.04 \mathrm{ppm}, 0.421-$ $0.02 \mathrm{ppm}$ and $0.871-0.03 \mathrm{ppm}$ for Nickel in L. harak, C. minata and T. maxima, respectively. However, vanadium recorded $0.010-0.00 \mathrm{ppm}, 0.014-0.01 \mathrm{ppm}$ and $0.042-$ $0.00 \mathrm{ppm}$ for L. harak, C. minata and T. maxima, respectively. These results were agreed with who worked on bioaccumulation of nickel and vanadium in tissues (gills, liver, intestine and kidney) of the catfish Clarias batrachus, however, results related to copper concentrations in Oreochromis mossambicus were in close agreement with the present findings, similarly T. maxima results obtained were in line with those obtained by [15-17].

\section{Conclusion}

In conclusion, the pollutants studied were found to be highly poisoning and lethal for the experimented animals. In this experiment no response was detected in lower concentrations of nickel and copper i.e. 4 ppm and $32 \mathrm{ppm}$, while a highly response of the pollutant vanadium was detected in the same concentrations. For the three populations highest LT50 occurred at a concentration of 64 ppm of nickel and copper with significant variation in response between fish species and mollusc $(p<0.05)$, and the highest LT50 of vanadium occurred at concentration of 4 ppm with significant variation in response between fish species and mollusc $(p<0.05)$. For copper, variations between the two fish species were not significant $(p>0.05)$, however the variation between fish species and mollusc was highly significant $(\mathrm{p}<0.05)$.

Although high concentration of nickel and copper were found in tissues of the experimented animals compared to vanadium, never the less, the results indicated that vanadium was highly poisoning than nickel \& copper.

\section{References}

[1] De Oliveira Ribeiro CA, Belger L, Pelletier E. and Rouleau C. (2002). Histopathological evidence of inorganic mercury and methyl mercury toxicity in the arctic charr (Salvelinusalpinus). Environ. Res.; 90 (3): 217-25. 
[2] Holleman, M. (2004). The lingering lessons of the Exxon Valdez spill. Common Dreams.org.

[3] Stephen J. W., David M. V., Withrow and McEwen's. (2007) Small Animal Clinical Oncology, Elsevier, ISBN, p. 73-4.

[4] Persga (2002). Status of the living marine resources in the Red Sea and Gulf of Aden and their management Vol. 3b, strategic action programmer (SAP). Washington, DC. USA.

[5] Idris A. M, Eltayeb M. A. H, Sanja, S. Potgieter-Vermaak, Van Grieken, R., Potgieter, J. H. (2007) Assessment of heavy metals pollution in Sudanese harbour along the Red Sea Coast. Microchemical Journal 87 (2007) 104-112.

[6] Ali, A. Y, Idris, A. M, Ebrahim AM, Eltayeb, M. A (2017) Brown algae (Phaeophyta) for monitoring heavy metals at the Sudanese Red Sea coast. Appl. Water Sci. 1-8.

[7] Meohan, W. R., Norris, L. A., Sears, H. S. (1974). Toxicity of various formulations of 2, 4D to Salmonids in south east Alaska. J. Fish. Res. Bd. Can. 31, 480-485.

[8] Lioyd, R. (1979). An outline scheme for evaluating the hazards to aquatic life from chemical pollution and obtaining water quality criteria sixth $\mathrm{FAO} /$ Sidaw workshop on aquatic pollution in relation to protection of living resources. Mombassa - Kenya. FAW Rome T. F - RAF 112, 154-165.

[9] Gesamp (IMO/ FAO / UNESCO / WMO /IAEA / UN / UNEP) Joint Group of Expert on the Scientific Aspects of Marine Pollution (1988). Review of the Health of the Oceans. Reports and Studies No. 33. Paris.

[10] Ginley Mc, M. (2008). Red Sea large marine ecosystem In: Encyclopedia of earth. Eds. Culture J. Cleveland (Washington, D. C.: Environmental Information Coalition, National Council for Science and the Environment).
[11] Doudoroff, P., Andereson, Burdick G. E., Galtsoff p. s., Hant, W. B., Patricj, R., Stong, E. W., and Van Horn W. M. (1951). Bioassay methods for the evaluation of acute toxicity of industrial wastes to fish, sewage Ind. Wastes; 23 (11): 130 136.

[12] Rompe, JD, P Eysel, J Zöllner, B Nafe, J Heine (1999). Degenerative lumbar spinal stenosis. Neurosurg. Rev 22, 102106.

[13] Naz. S and Javed. M (2013). Studies on the toxic effects of Lead and Nickel mixture on two fresh water fishes, Ctenopharyngodon idella and Hypophthalmichthys molitrix, The Journal of Animal \& Plant Sciences, 23 (3), pp. 798-804.

[14] Yousafzai, A. M., A. R. Khan and A. R. Shakoori. (2009). Trace Metal Accumulation in the Liver of an Endangered South Asian Fresh Water Fish Dwelling in Sub-Lethal Pollution,. Pakistan J. Zool., vol. 41 (1), pp. 35-41.

[15] Ray, D., Banergee, S. K. and Chatterjee, M. (1990). Bioaccumulation of nickel and vanadium in tissues of the catfish Clarias batrachus, Journal of Inorganic Biochemistry Volume 38, Issue 3, pp. 169-173.

[16] Raheela, S, MZ Khan, Y Ghazala, SA Ghalib (2014). Levels of heavy metals (cadmium, chromium, copper and lead) on water and selected tissues of Oreochromis mossambicus from different locations of Malir River, Karachi. Canadian Journal of Pure \& Applied Sciences. Vol. 8, No. 3, pp. 3011-3018.

[17] Mohammed, T. A. A., E. M, Mohamed, Y. M. Ebrahim, A. A. Hafez and R. M. E Zamzamy (2014) Some metal concentrations in the edible parts of Tridacna maxima, Red Sea, Egypt, environmental earth science, Environ Earth Sci. (2014) 71: 301-309. 